\title{
Multi-Hazard Early Warning System (MHEWS) Assessment Methodology for Schools
}

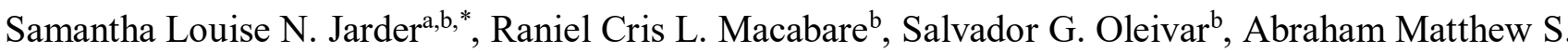 \\ Carandang ${ }^{\mathrm{b}}$, Patrick Shaun N. Ngo ${ }^{\mathrm{b}}$, Richard M. de Jesus ${ }^{\mathrm{b}}$, Lessandro Estelito O. Garciano ${ }^{\mathrm{b}}$, Andres \\ Winston C. Oreta ${ }^{b}$ \\ ${ }^{a}$ Urban and Civil Engineering, Tokyo City University, 1 Chrome-28-1Tamazutsumi, Setagaya City, Tokyo, ZIP 158-0087, Japan \\ ${ }^{b}$ Civil Engineering Department, De La Salle University, Taft Avenue, Malate, Manila City, 1004, Philippines \\ Corresponding author: ${ }^{*}$ samiejarder@gmail.com
}

\begin{abstract}
Schools play an important role in any community because children spend most of their time in schools for their education. Unfortunately, schools are exposed to natural hazards such as earthquakes, typhoons, and floods like other structures. However, implementing an effective Early Warning System (EWS) can help school administrators, occupants, and communities prepare against these hazards. EWS is an essential component of a disaster risk reduction management (DRRM) plan. Its purpose is to generate and disseminate timely and meaningful information of possible extreme events to administrators and eventually to the students. However, it is difficult to ascertain the quality of a school's EWS to address any upcoming hazards. With this, the authors designed a workshop with toolkits to guide school administrators in evaluating their organizational structure within the context of DRR. The toolkits assessed the soft and hard measures of the school, particularly its DRRM and EWS. A method was developed to measure the EWS in schools based on the toolkits. A radar scoring system was used to measure the school's key elements: Risk Knowledge, Monitoring and Warning Services, Dissemination and Communication, Response Capabilities. Indices for each element and EWS as a whole were obtained. Modes of warning and communication were ranked. In Lipa City's case, the results showed that the schools have an average of 74.050 EWS index, meaning the EWS is of good quality but can still be improved. This method can be applied to other schools to assess their EWS.
\end{abstract}

Keywords - Early Warning System; disaster risk reduction and management; disaster preparedness; disaster response.

\section{INTRODUCTION}

Schools are an essential part of a community. It is where children spend most of their time for education and contribute to the area's socio-economic growth. Being situated in the Pacific Ring of Fire, countries like the Philippines are plagued with natural hazards such as typhoons, flooding, and earthquakes [1]. The country is considered highly vulnerable to natural disasters, ranking third out of 173 [1]. Unfortunately, schools are exposed to these hazards that can bring about cancellation of classes causing momentary educational progress of school children [1]. Exposure to natural disasters can have long-term effects on a child's development and affect them as adults [2], [3], both mentally and physically. This makes their group highly vulnerable to hazards, especially when they are in school and separated from their parents [2]. Disasters also impact a child's learning due to classes being disrupted [4].

Natural disasters such as earthquakes and typhoons severely damaged schools in recent years, causing structural and non-structural damages. Their devastating effects have deteriorated the quality of education in affected areas through the disruption of classes. Table I lists catastrophic events from 2013 onwards that have led to the widespread destruction of lives and property, especially for schools [5][9].

To avoid such damages due to future hazards, proper planning and preparations can help minimize class suspensions, damages, and losses [10]. One way for schools to be prepared against these hazards is to implement Early Warning Systems (EWS). The United Nations Disaster Risk Reduction (UNDRR) defined EWS as "An integrated system of hazard monitoring, forecasting and prediction, disaster risk 
assessment, communication and preparedness activities systems, and processes that enable individuals, communities, governments, businesses, and others to take timely action to reduce disaster risks in advance of hazardous events" [11]. EWS is a set of capabilities needed to generate and disseminate timely and meaningful information on the possible extreme events or disasters threatening lives.

TABLE I

EFFECTS OF NATURAL DISASTERS ON SCHOOLS

\begin{tabular}{|c|c|c|}
\hline $\begin{array}{l}\text { Type of } \\
\text { Natural } \\
\text { Disaster }\end{array}$ & Event & Impact and Damages \\
\hline \multirow{3}{*}{ Earthquake } & $\begin{array}{l}\text { Luzon Earthquake } \\
\text { (Apr. 2019) Mw } 6.1\end{array}$ & $\begin{array}{l}\text { - } 528 \text { schools sustained } \\
\text { damages in Regions I, } \\
\text { III, IV-A and the } \\
\text { National Capital Region } \\
\text { (NCR) } \\
\text { - } 1,653 \text { schools } \\
\text { suspended on that day }\end{array}$ \\
\hline & $\begin{array}{l}\text { Surigao Earthquake } \\
\text { (Feb.2017) Mw } 6.7\end{array}$ & $\begin{array}{l}\text { - } 47 \text { schools sustained } \\
\text { both structural and non- } \\
\text { structural damages in } \\
\text { the province of Surigao } \\
\text { del Norte alone. } \\
\text { - } 5 \text { class days were } \\
\text { suspended }\end{array}$ \\
\hline & $\begin{array}{l}\text { Bohol Earthquake } \\
\text { (Oct. 2013) Mw } 7.2\end{array}$ & $\begin{array}{l}\text { - } 82 \text { schools with } \\
\text { sustained damage: } 28 \text { in } \\
\text { Cebu, } 32 \text { in Bohol, } 6 \text { in } \\
\text { Siquijor, } 7 \text { in Iloilo, } 9 \text { in } \\
\text { Negros Occidental }\end{array}$ \\
\hline \multirow{3}{*}{ Typhoon } & $\begin{array}{l}\text { Haiyan (local name } \\
\text { Yolanda) (Nov. } \\
\text { 2013) }\end{array}$ & $\begin{array}{l}\text { - } 5.9 \text { million children } \\
\text { affected. } \\
\text { - } 90 \% \text { of schools } \\
\text { structurally damaged } \\
\text { - Temporary learning } \\
\text { spaces were set up }\end{array}$ \\
\hline & Basyang (Feb. 2018) & $\begin{array}{l}\text { - School supplies and } \\
\text { equipment destroyed } \\
\text { due to flash flooding } \\
\text { and heavy. } \\
\text { - Class suspension up to } \\
3 \text { days in several } \\
\text { regions }\end{array}$ \\
\hline & $\begin{array}{l}\text { Super Typhoon } \\
\text { Mangkhut (local } \\
\text { name Ompong) } \\
\text { (Sept. 2018) }\end{array}$ & $\begin{array}{l}\text { - Most schools resumed } \\
\text { after } 2 \text { to } 3 \text { days, but } \\
\text { some resumed after } \\
\text { almost two weeks. } \\
\text { - Schools served as } \\
\text { evacuation centers. } \\
\text { - } 2.62 \text { billion pesos } \\
\text { accumulated worth of } \\
\text { damages }\end{array}$ \\
\hline
\end{tabular}

However, EWS are commonly used in flood-prone areas and coastal areas that are exposed to tsunami hazards [12], [13] and usually on a wider scope or community level, not only on a smaller scale like a school community. EWS is considered people centered. This means that for the system to work effectively, active participation of those involved or at risk is expected [11],[14]. Moreover, studies focus on the devices and technologies of EWS such as SMS and alarms [15], [16] compared to participant involvement. Experts and researchers suggest incorporating EWS with Organizational Resilience [17], [18] Studies showed that Organizational Resilience could minimize the negative impacts of technical issues and limitations of the EWS technologies [17].

EWS has four key elements. These elements are Risk Knowledge, Response Capabilities, Monitoring and Warning Services, and Dissemination and Communication. According to the United Nations General Assembly (UNGA), if one element fails and there is insufficient coordination, then the whole system would fail [11]. Currently, the Philippines has a well-developed EWS at the national level [19]. However, no study or result regarding the EWS of schools or small-scaled communities is greatly affected by hazards.

Therefore, an emphasis on promoting school safety with EWS is necessary. Many agencies advocated the Comprehensive School Safety (CSS), using three pillars to reduce school hazards and disasters. These pillars are Pillar 1: Safe Learning Facilities; Pillar 2: School Disaster Management; and. Pillar 3: Risk Reduction and Resilience Education [20]. The Department of Education (Philippines) adapted the CCS framework in its DRR plan for schools. However, there are still gaps that need to be filled [21],[22].

To address the resilience of schools to multi-hazards, a team of researchers from the United Kingdom and the Philippines, initiated the PRISMH (Philippine Resilience of Schools to Multi-Hazard) Project, in which the CCS pillar on Safe Learning Facilities is reported [23]. Another component of the PRISMH Project initiated by the Philippine team to address pillar 2 of the CCS on school disaster management is "Strengthening ORDER in Schools (SOS)" and accompanying toolkits. ORDER in SOS stands for "Organizational Resilience in Disaster and Emergency Response." The SOS work package consists of workshops and toolkits that are designed to guide school administrators and faculty in evaluating their organizational structure within the context of DRR. This was used as a tool to address the CSS gaps.

\section{A. Objectives}

The project's main objective is to guide the school administrators in evaluating its organizational structure within the context of Disaster Risk Reduction (DRR). In order to achieve this, the following are the specific objectives:

- Conduct a workshop to educate school administrators on the concept of Organizational Resilience.

- Let the participants of the workshop assess the Organizational Resilience of their respective schools.

- Assess the emergency preparedness of the schools using EWS based on the SOS. Toolkits developed.

\section{B. Framework}

The general idea for this research is to quantify and improve the level of resilience of schools. However, general resilience cannot be measured since the concept is too broad and complex. Hence, this study focuses on the Early Warning System and its elements and its relevance to DRR. Fig. 1 shows the conceptual framework for this paper. It shows the outer circle is Resilience, as it is the general goal of the study. 
As defined by the UNGA, Resilience is "The ability of a system, community or society exposed to hazards to resist, absorb, accommodate, adapt to, transform and recover from the effects of a hazard in a timely and efficient manner, including through the preservation and restoration of its essential basic structures and functions through risk management" [11].

Arup developed a roadmap to measure the resilience of a building called the REDi Rating System (Resilience-based Earthquake Design Initiative for the Next Generation of Buildings). There are three criteria for Resilient Design and Planning. These are Organizational Resilience, Building Resilience, and Ambient Resilience [24].

The SOS Project under PRISMH adapted the REDi Organization Resilience concept to schools. Organizational Resilience is mostly highlighted in the context of business. This was conceptualized in order for businesses and organizations to operate if and when conflict or disasters arise with minimal or no losses [25], [26]. This paper focuses on this aspect of resilience, as it is a fundamental component in achieving an effective EWS in school communities. Questions from the toolkits addressing the EWS of the schools were categorized per element. The figure also shows that each element is interdependent with one another.

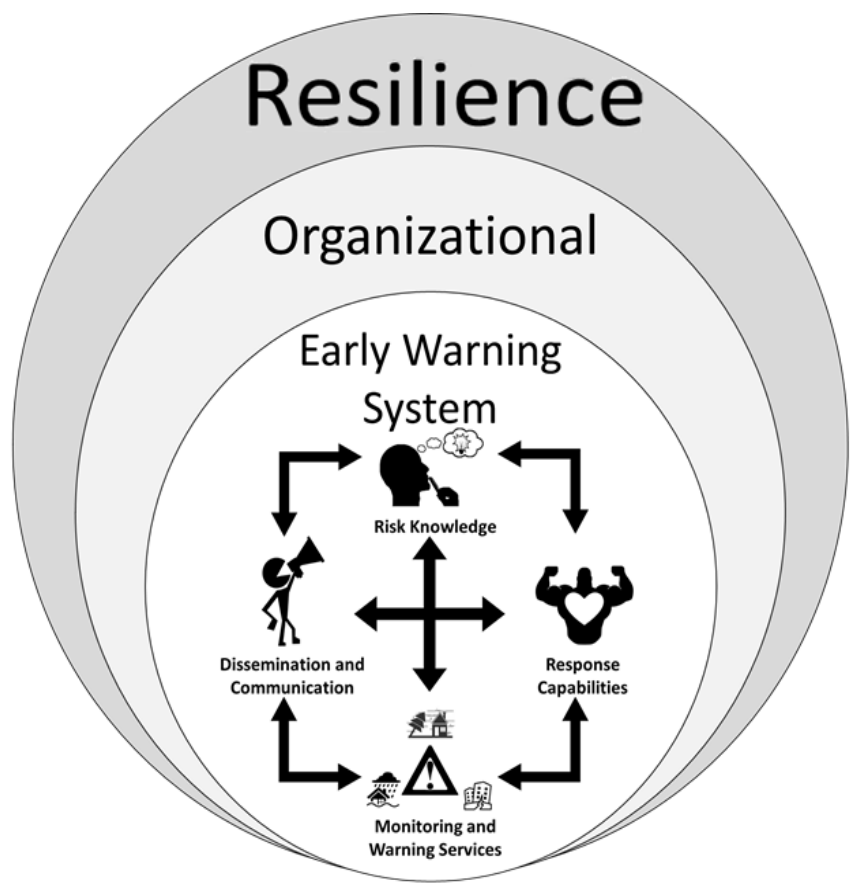

Fig. 1 Conceptual Framework

The framework shows that an EWS has four key elements: (a) Risk Knowledge, (b) Response Capabilities, (c) Monitoring and Warning Services, and (d) Dissemination and Communication. Each element is required for the system to function properly and efficiently.

The first key element is Risk Knowledge. This asks the question, "How much do you know?". This element aims to measure the school's awareness and preparedness through data collection and risk assessments. It also seeks to educate people of the impending risks that might occur. Examples of this include risk assessments and maps, which help motivate people, prioritize early warning system needs, and guide preparations for disaster prevention and responses [11], [27], [28], [29].

Response Capabilities asks the question, "How prepared are you?". This element aims to build national and communication response capabilities. The response is considered to address the urgent and short-term needs of those affected. This element focuses more on the strategy and knowledge the occupants have before, during, and after the occurrence of a hazard. This includes the planning and measures the school did and the response of the occupants to the procedures [11], [27], [28], [29].

Monitoring and Warning Services asks the question, "How did you know?" Monitoring of Hazards is expected to work for 24 hours since any hazard can occur anytime. This element aims to determine whether there is an upcoming hazard and how to warn the occupants [11], [27], [28], [29].

The last element is Dissemination and Communication. It asks the question, "How did you inform?". The Dissemination and Communication element focuses on the flow and organization of giving out information. This may be confused with a warning; however, the difference is: warning focuses on alerting the occupants of an upcoming hazard, while communication focuses more on the information and announcements of the decision-maker [11], [27], [28], [29].

The concept of this paper shows a way to assess each element and as a whole. It also pinpoints which element is strong and/or weak in the system. This could help administrators where they should improve and what they should invest in their schools.

\section{Materials AND Methods}

There are three main parts, namely, the input, analysis, and output. For the input, The SOS. Project conducted a workshop where the participants answered the toolkits. The workshop was designed to educate the school administrators about the hazards their schools are vulnerable to, understand the importance of preparation and awareness to the occupants of their facility, and guide them to evaluate the school's organizational resilience through the toolkits. This was done to ensure the consistency of the participant's understanding of the questions and answers with one another.

There are 8 toolkits for the participants to answer, as shown in Table II. The toolkits were designed to evaluate each element of the Early Warning System. The toolkits were then collected and the answers of the participants were recorded Reduction and Management Manual, Department of Education (DepEd) Health and Safety Protocols, National Building Code of the Philippines (NBCP), Multi-hazard Early Warning System: A Checklist [24], [27], [30], [31], [32].

Once the answers were recorded and analyzed, each element's index was determined and then categorized. A radar scoring system was utilized to produce an output. This system visually shows how much the schools need to improve in a particular element and where they excel. The scoring system was designed to inform the administrators of their schools' standing for each element. 
TABLE II

TOOLKITS USED IN THE STUDY

\begin{tabular}{|c|c|}
\hline Toolkit & Purpose \\
\hline Toolkit \#1: Risk & Used to assess the awareness of \\
\hline Knowledge & the school to natural hazards. \\
\hline Toolkit \#2: SDRRM & Determines who are the officers \\
\hline Composition and & involved in the School Disaster \\
\hline Functions & Risk Reduction and Management. \\
\hline Toolkit\#3: Hazard & Used to assess the capacity of the \\
\hline Preparedness & $\begin{array}{l}\text { DRR officers and students to } \\
\text { respond before, during, and after } \\
\text { disasters }\end{array}$ \\
\hline \multirow{5}{*}{$\begin{array}{l}\text { Toolkit\#4: Monitoring \& } \\
\text { Warning Services }\end{array}$} & Identifies who is the decision - \\
\hline & maker of the school for \\
\hline & suspending classes. It also \\
\hline & inspects the status of the \\
\hline & $\begin{array}{l}\text { monitoring devices available in } \\
\text { the school. }\end{array}$ \\
\hline \multirow{6}{*}{$\begin{array}{l}\text { Toolkit\#5: Communication } \\
\text { \& Dissemination }\end{array}$} & Assesses the emergency \\
\hline & communication system of the \\
\hline & $\begin{array}{l}\text { school to students, parents, } \\
\text { personnel, and government }\end{array}$ \\
\hline & agencies. It also identifies the \\
\hline & usability and priority of the \\
\hline & $\begin{array}{l}\text { communication devices installed } \\
\text { in the school. }\end{array}$ \\
\hline Toolkit\#6: Evacuation & Evaluates the school safety during \\
\hline Safety & evacuation and identifies the \\
\hline & $\begin{array}{l}\text { standard procedure of evacuation } \\
\text { of the school. }\end{array}$ \\
\hline
\end{tabular}

\section{Scoring}

To analyze the results, the concept of the "Weighted Average" was used [33]. Based on the toolkits, the participants' answers were recorded and were given a weight depending on the level of vulnerability and risk the schools are exposed to. The weights of the answers, $w_{\mathrm{i}}$, are 3, 2 and 1; where 3 is low risk, 2 is medium risk and 1 is high risk.

Each question in the toolkit falls under a key element of the EWS. The Raw Score, $R_{k}$, can be obtained in Eq. 1 where, $n_{i}$ is the question weight. In this paper, each question has the same weight or importance to one another in each element, $k$, therefore it was assumed that $n_{i}$ is equal to 1 . The perfect score for each element, $P_{k}$, as shown by Equation 2, is equal to the total questions in each element, $N_{k}$, multiplied to 3 ; since 3 means that there is low risk.

$$
\begin{gathered}
R_{k}=\sum_{i=1}^{j} n_{i} \cdot w_{i} \\
P_{k}=N_{k} \cdot 3 \\
I_{k}=100 \cdot \frac{R_{k}}{P_{k}} \\
I=\operatorname{Average}\left(I_{k}\right)
\end{gathered}
$$

The Index for each Element, $I_{k}$, can be obtained in Equation 3. The ratio of $R_{k}$ and $P_{k}$ was multiplied to 100 so the perfect index is equal to 100 . The EWS Index, $I$, is the average of all the Element Index; this shows that each element is equal to one another. The lowest possible score is 33.33, and 100 is the maximum score. The raw scores were divided

\begin{tabular}{|c|c|c|c|c|c|c|}
\hline Stars & $\begin{array}{l}\text { Raw } \\
\text { Score }\end{array}$ & $\begin{array}{c}\text { Risk Knowledge } \\
\text { Remarks }\end{array}$ & $\begin{array}{c}\text { Response } \\
\text { Capabilities } \\
\text { Remarks } \\
\end{array}$ & $\begin{array}{c}\text { Monitoring \& } \\
\text { Warning Services } \\
\text { Remarks } \\
\end{array}$ & $\begin{array}{c}\text { Communication } \& \\
\text { Information } \\
\text { Dissemination Remarks }\end{array}$ & EWS Remarks \\
\hline$\star$ & $\begin{array}{l}33< \\
I_{k} \\
\leq 46\end{array}$ & $\begin{array}{l}\text { The school is } \\
\text { highly exposed to } \\
\text { all-natural } \\
\text { hazards. The } \\
\text { occupants are } \\
\text { unaware of the } \\
\text { risk they are in. }\end{array}$ & $\begin{array}{l}\text { Occupants have no } \\
\text { idea what to do in the } \\
\text { hazard. Evacuation } \\
\text { and path are not } \\
\text { clear. This may lead } \\
\text { to high casualties. } \\
\text { Being trapped and } \\
\text { stranded can happen. }\end{array}$ & $\begin{array}{l}\text { No monitoring of } \\
\text { hazards. Warning } \\
\text { system does not } \\
\text { exist. The warning } \\
\text { does not reach the } \\
\text { occupants. }\end{array}$ & $\begin{array}{l}\text { The school does not have } \\
\text { a communication plan. } \\
\text { The means to } \\
\text { disseminate information } \\
\text { to the students is not } \\
\text { effective and not } \\
\text { functioning. }\end{array}$ & $\begin{array}{c}\text { The Early Warning } \\
\text { System fails to } \\
\text { address the hazard. } \\
\text { The occupants are } \\
\text { highly at risk. }\end{array}$ \\
\hline$\star \star \star$ & $\begin{array}{c}46< \\
I_{k} \\
\leq 59\end{array}$ & $\begin{array}{l}\text { The school is } \\
\text { exposed to some } \\
\text { and/or almost all } \\
\text { hazards. The } \\
\text { preparation and } \\
\text { awareness of the } \\
\text { occupants are not } \\
\text { enough. }\end{array}$ & $\begin{array}{l}\text { Evacuation strategies } \\
\text { are not enough. } \\
\text { Occupant's } \\
\text { knowledge requires } \\
\text { improvement. } \\
\text { Assistance is } \\
\text { required. Being } \\
\text { trapped and stranded } \\
\text { can happen. }\end{array}$ & $\begin{array}{l}\text { Monitoring and } \\
\text { warning systems are } \\
\text { not enough. The } \\
\text { warning does not } \\
\text { reach most of the } \\
\text { occupants. }\end{array}$ & $\begin{array}{l}\text { Communication Planning } \\
\text { and Modes of } \\
\text { Communication is not } \\
\text { enough. Required to } \\
\text { improve planning, and } \\
\text { efficiency of } \\
\text { communication is } \\
\text { needed. }\end{array}$ & $\begin{array}{l}\text { EWS is not enough } \\
\text { to address hazards. }\end{array}$ \\
\hline 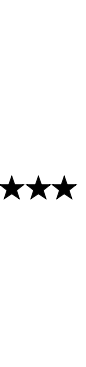 & $\begin{array}{l}59< \\
I_{k} \\
\leq 74\end{array}$ & $\begin{array}{l}\text { The awareness of } \\
\text { the occupants is } \\
\text { enough } \\
\text { depending on the } \\
\text { level of hazard } \\
\text { the school is } \\
\text { exposed to. }\end{array}$ & $\begin{array}{l}\text { The Response } \\
\text { Capability of the } \\
\text { school meets the } \\
\text { minimum } \\
\text { requirement. Some } \\
\text { occupants have an } \\
\text { idea of what to do in } \\
\text { case of hazards. } \\
\text { Assistance may be } \\
\text { needed. }\end{array}$ & $\begin{array}{l}\text { Monitoring and } \\
\text { warning system } \\
\text { meets the minimum } \\
\text { requirement. } \\
\text { Warning reaches the } \\
\text { occupants. } \\
\text { Efficiency and } \\
\text { functionality may } \\
\text { require } \\
\text { improvement. }\end{array}$ & $\begin{array}{l}\text { Communication Planning } \\
\text { or Modes may require } \\
\text { improvement. Answers } \\
\text { need to be reviewed } \\
\text { where the school lacks. } \\
\text { Otherwise, the school } \\
\text { meets the minimum } \\
\text { requirement. }\end{array}$ & $\begin{array}{c}\text { Minimum Early } \\
\text { Warning Intervention } \\
\text { and Hazard } \\
\text { Preparation have } \\
\text { been met. Review the } \\
\text { results of other } \\
\text { Elements where } \\
\text { improvements are } \\
\text { required. }\end{array}$ \\
\hline$\star \star \star$ & $74<$ & $\begin{array}{l}\text { The school is } \\
\text { somewhat and }\end{array}$ & $\begin{array}{l}\text { Some occupants have } \\
\text { an idea of what to do }\end{array}$ & $\begin{array}{l}\text { Hazards are being } \\
\text { monitored. The }\end{array}$ & $\begin{array}{l}\text { Planning is done. Modes } \\
\text { of Communication may }\end{array}$ & $\begin{array}{c}\text { Each element of } \\
\text { EWS in school is of }\end{array}$ \\
\hline
\end{tabular}
into intervals.

TABLE III

SUMMARY AND INTERPRETATION OF SCORES 


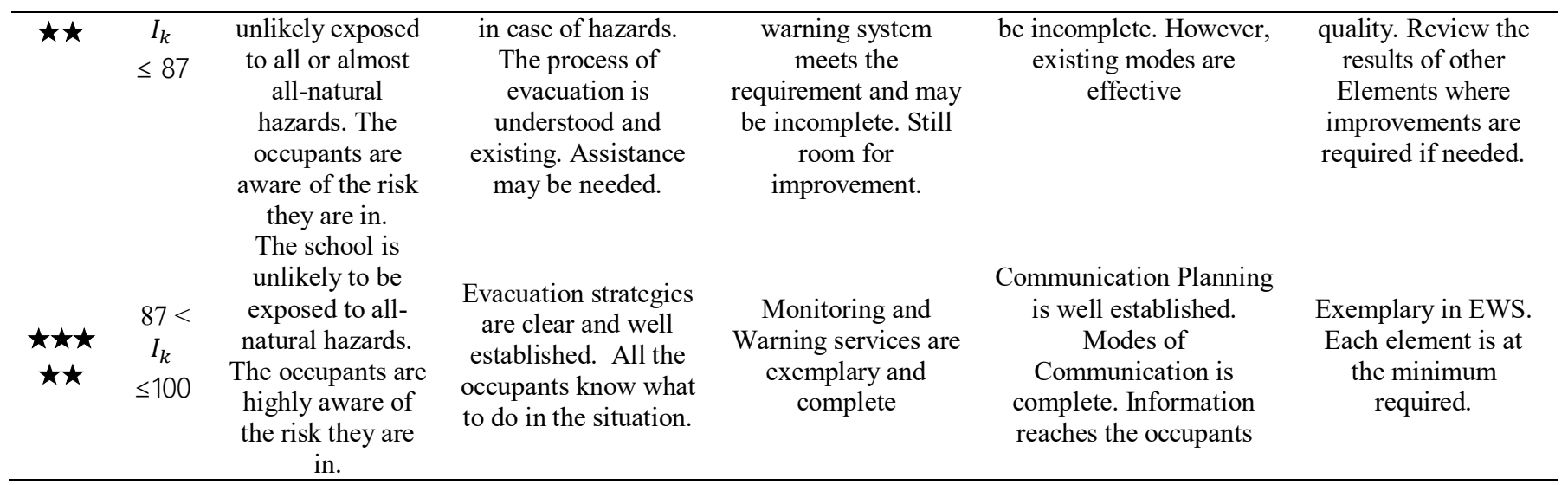

Table III shows the summary and interpretation of the raw scores for each element. The matrix's content was formulated based on simulations of possible participants' possible scores at different scenarios and conditions. Answers in the toolkit were simulated to numerous conditions and combinations for the categories to be defined for each index. The schools should strive to get three stars in all Elements. If the schools have less than three stars in one element, the EWS still fails even if it reaches the 3-star category. This is to ensure that if one element is insufficient, the whole system will fail.

\section{RESULTS AND DISCUSSION}

The toolkits were first tested in Lipa City. Based on DepEd's national school building inventory, there are at least 80 primary and secondary schools inside Lipa city; $18 \%$ are secondary schools. The number of participants present in the workshop can be found in Table IV. While not all schools were present in the workshop, the sample size can be considered a good representation of Lipa City schools.

TABLE IV

PARTICIPANTS FOR THE TOOLKIT

\begin{tabular}{cc}
\hline Department & DepEd \\
\hline School Division & Lipa \\
\hline No. of Schools (PS) & 66 \\
\hline No. of Schools (SS) & 15 \\
\hline Total No. of Schools & 81 \\
\hline Participants in the Toolkits & 79 \\
\hline Population & N/A \\
\hline
\end{tabular}

Based on the toolkits, the answers of the participants were recorded and analyzed.

\section{A. The SOS. Project: DepEd-Lipa City}

The city is located in the southern part of Luzon; $80 \mathrm{~km}$ south of Manila. It is a part of Region IV-A; and is the 6th district of Batangas province.

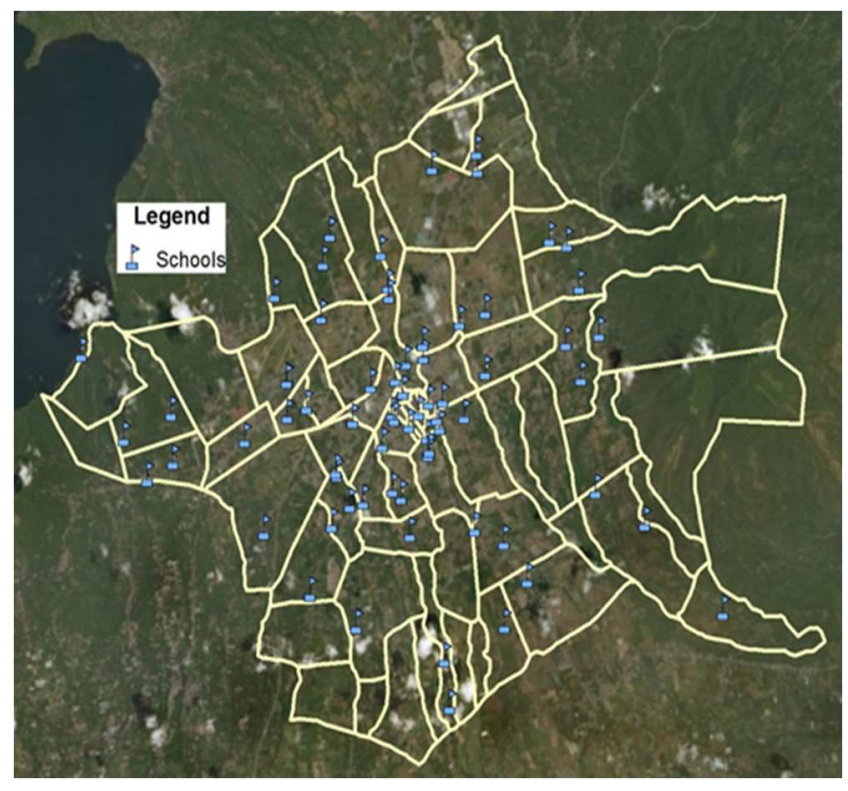

Fig. 2 Location of the participating schools in Lipa City

Figure 2 shows the map of Lipa City, Batangas, and the participating schools of Lipa City for the survey. These were produced using ArcMap. The most common natural hazard experienced by Lipa City and in the whole Batangas province are earthquakes. On the 11th of August 2017, it was hit by a 6.3 Mw earthquake. The city is also one of many locations affected by the Taal Volcano 2020 eruption.

Lipa City and the whole Batangas province usually experience earthquakes due to the presence of numerous fault lines. Fig. 3 shows the surrounding fault lines in the province of Batangas. Four fault lines are surrounding it; namely, Aglubang, Lubang, Infanta, and the West Valley fault, in which the last one mentioned is the nearest fault to the venue of the workshop in Barangay Sampaguita in Lipa City at 29. 3 kilometers [34]. 


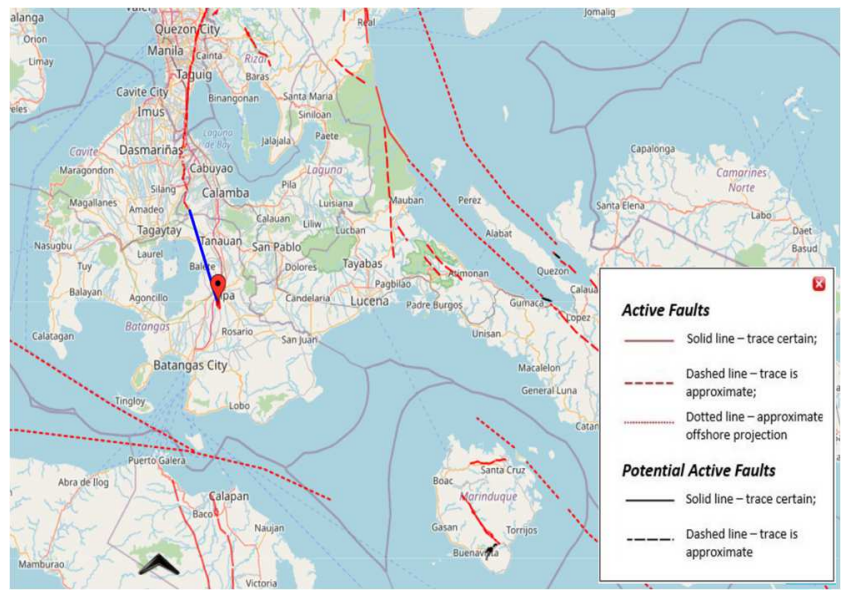

Fig. 3 Earthquake hazard map of Region IV-A (source: PHIVOLCS).

\section{B. Risk Knowledge}

The assessment for Risk Knowledge is based on toolkit 1. Three considerations were evaluated on this assessment: (1) hazard exposure, (2) hazard mitigation measures, and (3) DRR implementation in the education curriculum. For Risk Knowledge, the questions under this toolkit were grouped to Hazard Vulnerability and the EWS Intervention Level. Hazard exposure counts the number of times a school was exposed to the hazard annually. Mitigation measures identify if the school had a hazard map available and whether measures were made to mitigate the hazard.

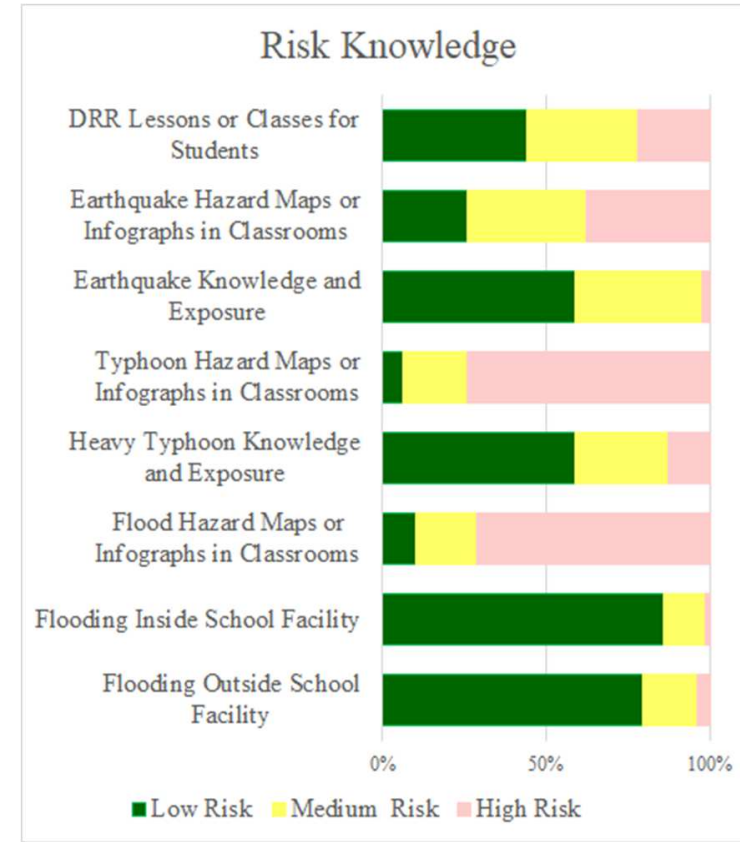

Fig. 4 Results for Risk Knowledge

Fig. 4 shows the Results for Risk Knowledge. It shows that most schools do not have hazard maps on flooding and typhoons, and most of the schools at least have available hazard maps for earthquakes. It also shows the lesser the hazard frequency, the higher the possibility of schools having hazard maps and utilizing them for safety measures. Among the three hazards, the earthquake is the most difficult one to be forecasted, and this may be the reason why most of the schools focus on having their hazard map compared to the others; however, this needs further studies in order for the conclusion to be verified in future surveys.

\section{Response Capabilities}

The Response Capability assessment is based on toolkits 3 and 6. It assesses hazard preparedness, evacuation, and emergency supply kits. The questions from these toolkits were grouped into Occupant Knowledge and Evacuation Strategy. Occupant Knowledge refers to the level of knowledge and preparation the occupants have when a hazard occurs. The Evacuation Strategy refers to the level of action the school and administrators provided in case of evacuation and the response of its occupants.

Fig. 5 shows the results for Response Capabilities. The number of times DRR safety orientations were conducted in a school year. It can be observed in the graph that $95 \%$ of the schools have conducted in once a school year, while only $52 \%$ would conduct in quarterly. This would educate the occupants, specifically the student, on what to do when hazards would hit them during class hours. This includes evacuation procedures.

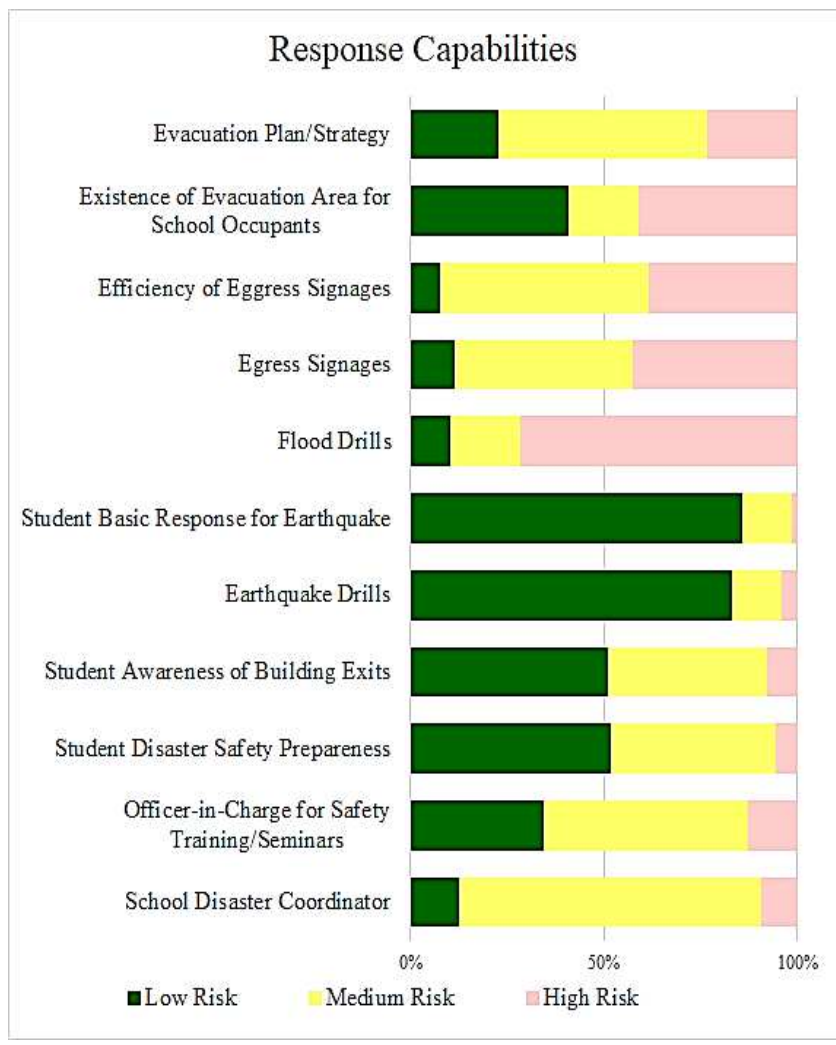

Fig. 5 Results for Response Capabilities

\section{Monitoring and Warning}

The Monitoring and Warning Element is based on Toolkit 4 of the SOS. Toolkits. The goal of the toolkit is to evaluate the existing monitoring and warning services in the school. The questions from this toolkit were designed to assess the school's monitoring actions and capabilities and the functionality and efficiency of existing warning devices.

Figure 6 shows the Results for the Monitoring and Warning Element. It also shows that most schools have a fully functioning alarm and sound system; however, it does not have or use sirens as a mode of warning for hazards. It also 
shows that most schools utilize a room-to-room warning method, although it is not fully functioning as the alarm and sound system.

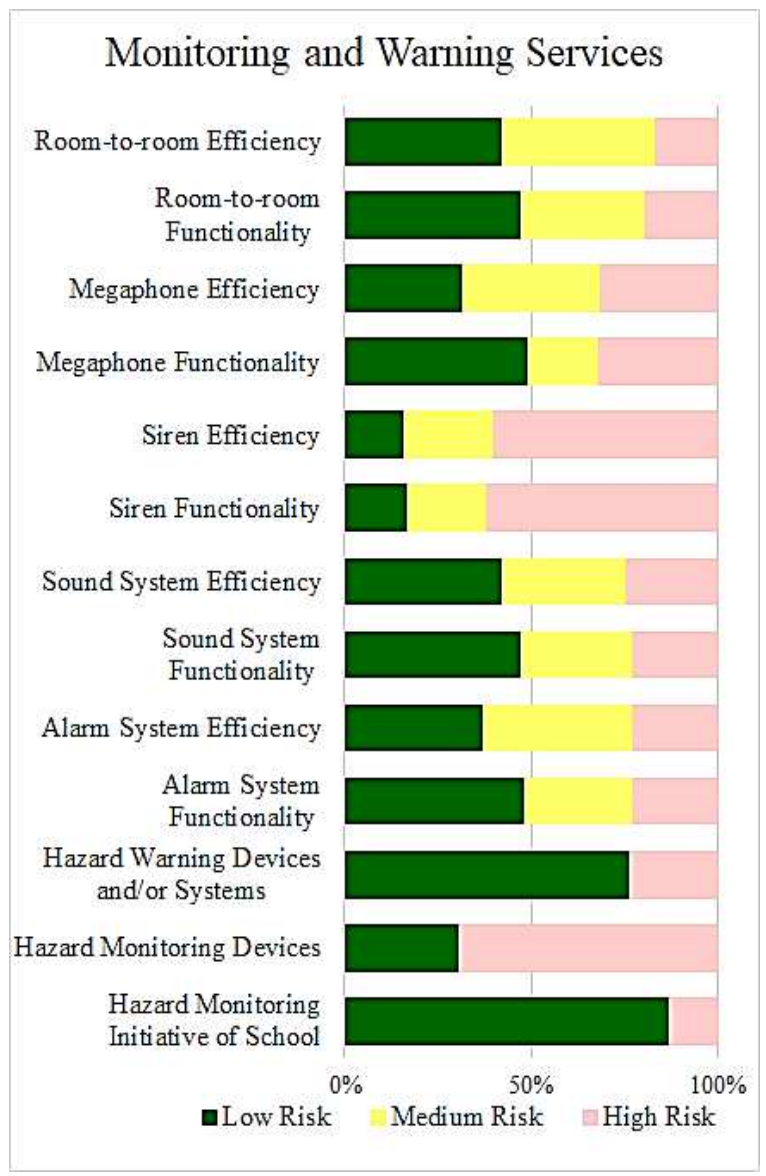

Fig. 6 Results for Monitoring and Warning Services

It can be observed that having a fully functioning warning system does not mean that it can be $100 \%$ efficient in the facility or cover all the occupants. It also shows that the most efficient warning mode is the room-to-room, followed by the sound system. The sound system is the most well-functioning and efficient means of warning based on the results.

TABLE V

RANKING OF WARNING DEVICES

\begin{tabular}{cccccc}
\hline $\begin{array}{c}\text { Mode of } \\
\text { Warning }\end{array}$ & $\begin{array}{c}\text { Alarm } \\
\text { System }\end{array}$ & $\begin{array}{c}\text { Sound } \\
\text { System }\end{array}$ & Siren & $\begin{array}{c}\text { Mega } \\
\text {-phone }\end{array}$ & $\begin{array}{c}\text { Room } \\
\text {-to- } \\
\text { room }\end{array}$ \\
\hline $\begin{array}{c}\text { Weight of } \\
\text { usage } \\
\text { frequency }\end{array}$ & 2.17 & 2.99 & $\begin{array}{c}3.8 \\
7\end{array}$ & 2.63 & 2.96 \\
\hline $\begin{array}{c}\text { Rank of } \\
\text { usage }\end{array}$ & 1 & 4 & 5 & 2 & 3 \\
\hline $\begin{array}{c}\text { Rank for } \\
\text { Functionality }\end{array}$ & 2 & 1 & 5 & 4 & 3 \\
\hline $\begin{array}{c}\text { Rank for } \\
\text { Efficiency }\end{array}$ & 3 & 2 & 5 & 4 & 1 \\
\hline $\begin{array}{c}\text { Overall } \\
\text { weigh }\end{array}$ & 2 & 2.33 & 5 & 3.33 & 2.33 \\
\hline $\begin{array}{c}\text { Overall } \\
\text { Rank }\end{array}$ & 1 & $2 / 3$ & 5 & 4 & $2 / 3$ \\
\hline
\end{tabular}

Table V shows the ranking modes of Warning Systems in schools. The table shows that the Alarm System is the most frequently used warning mode in the Schools in Lipa, followed by the Megaphone, Room-to-room, Sound System, and Siren. The sound system ranks the highest for the most available and workable, while the most efficient is the roomto-room method. The alarm system has the highest ranking in terms of usage, functionality, and efficiency for the overall ranking, followed by the sound system and the room-to-room method.

\section{E. Dissemination and Communication}

The Communication \& Dissemination is based on Toolkit 5 of the SOS. Toolkits. It assesses how efficient the school in communicating with its students and with other government agencies. The questions in this toolkit were designed to assess the dissemination planning of the school and the functionality and efficiency of existing warning devices.

It also includes the functionality and availability of modes of communications of schools for hazards in Lipa City, respectively. The results show that most schools utilized the telephone, website, social media, and SMS/Text Blast to communicate and are mostly fully functional.

TABLE VI

RANKING OF MODES OF COMMUNICATION

\begin{tabular}{ccccc}
\hline $\begin{array}{c}\text { Mode of } \\
\text { Communication }\end{array}$ & Telephone & Website & $\begin{array}{c}\text { Social } \\
\text { Media }\end{array}$ & $\begin{array}{c}\text { SMS/Text } \\
\text { Blast }\end{array}$ \\
\hline $\begin{array}{c}\text { Weight of } \\
\text { frequency of } \\
\text { usage }\end{array}$ & 2.97 & 3.34 & 1.86 & 1.58 \\
\hline Rank of usage & 3 & 4 & 2 & 1 \\
\hline $\begin{array}{c}\text { Rank for } \\
\text { Functionality }\end{array}$ & 3 & 4 & 2 & 1 \\
\hline $\begin{array}{c}\text { Rank for } \\
\text { Efficiency }\end{array}$ & 3 & 4 & 1.5 & 1.5 \\
\hline Overall weigh & 3 & 4 & 1.83 & 1.17 \\
\hline Overall Rank & 3 & 4 & 2 & 1 \\
\hline
\end{tabular}

Table VI shows the ranking of modes of communication used in schools to relay information related to hazards. The table shows that the SMS/Text Blast is the most frequently used communication mode in Lipa Schools, followed by social media, telephone, and website. For the most available and workable, the SMS/text blast method ranks the highest, while the most efficient is the SMS/text blast and Social Media method. For the overall ranking, SMS/text blast has the highest ranking in terms of usage, functionality, and efficiency, followed by social media and the telephone.

Fig 7 shows the results for the Communication and Information Dissemination Element. It shows the existence and access to an emergency contact in case of hazards. The results show that the majority of schools in Batangas do not have a complete and updated list of emergency contacts in case of hazards. It also shows the direct communication or coordination of schools to the LGU regularly. 


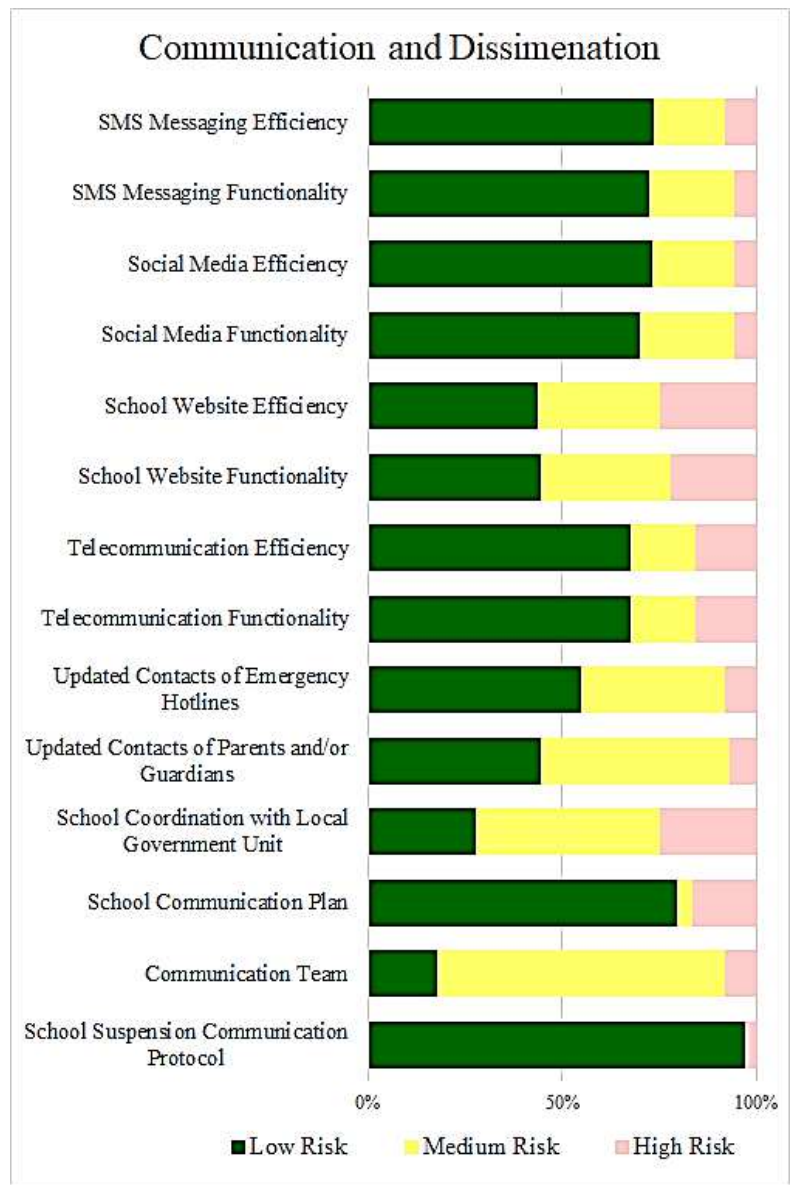

Fig. 7 Results for Communication and Information Dissemination

\section{F. Early Warning System}

In order to evaluate the Early Warning System as a whole, the radar scoring system was used. This system can identify which element the school requires to improve and where they excel. The EWS Index is obtained by taking the average of all the elements. The average signifies that each element is equal to one another.

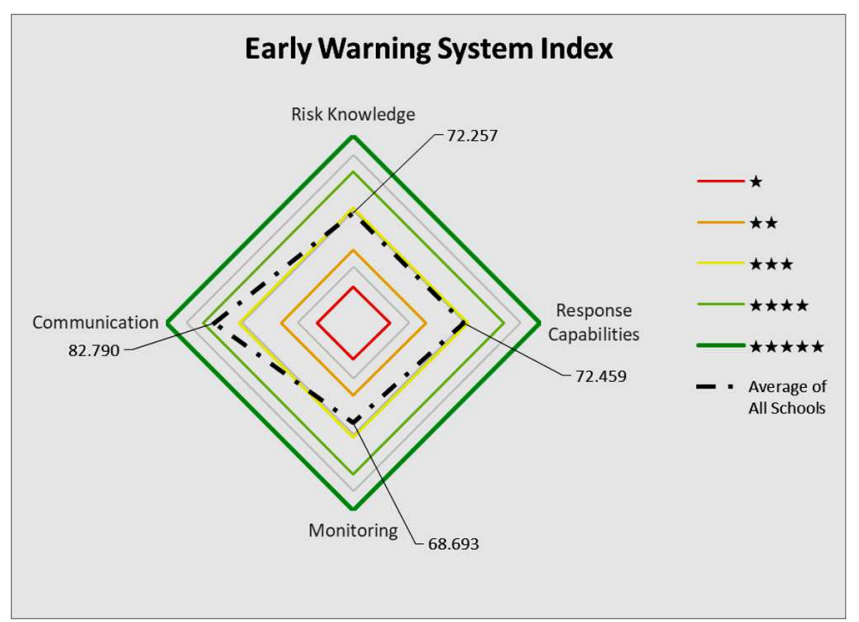

Fig. 8 Summary of the results of the Early Warning System in Lipa City

Fig. 8 shows the summary of the results of the SOS toolkits. The result includes the average of the scores of the schools in Lipa City at each element. The radar scoring system can help visualize which element needs to be improved and which the school is excelling at. The average of all schools in Lipa City has at least met the minimum requirement of each element of the EWS.

Table VII shows the matrix of the results of the average schools in Lipa City. The table includes the Category, Raw Score, Stars and Remarks. The category pertains to the Elements of the EWS and EWS as a whole. The Raw Score refers to the score obtained from answering the toolkits. The Stars refer to the level. Remarks would state the quality of the Early Warning System element and as a whole.

TABLE VII

SUMMARY OF THE AVERAGE RESULTS OF THE SCHOOLS OF LIPA CITY

\begin{tabular}{|c|c|c|c|}
\hline Category & $\begin{array}{l}\text { Raw } \\
\text { Score }\end{array}$ & Stars & Remarks \\
\hline Risk Knowledge & 72.257 & $\star \star \star$ & $\begin{array}{l}\text { The awareness of the occupants is } \\
\text { enough depending on the level of } \\
\text { hazard the school is exposed to. }\end{array}$ \\
\hline $\begin{array}{c}\text { Response } \\
\text { Capabilities }\end{array}$ & 72.459 & $\begin{array}{c}\star \star \\
\star\end{array}$ & $\begin{array}{l}\text { Monitoring and warning system } \\
\text { meets the minimum requirement. } \\
\text { Warning reaches the occupants. } \\
\text { Efficiency and functionality may } \\
\text { require improvement. }\end{array}$ \\
\hline $\begin{array}{l}\text { Monitoring and } \\
\text { Warning Services }\end{array}$ & 68.693 & 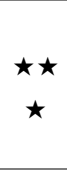 & $\begin{array}{l}\text { The Response Capability of the } \\
\text { school meets the minimum } \\
\text { requirement. Some occupants have } \\
\text { an idea of what to do in case of } \\
\text { hazards. Assistance may be } \\
\text { needed. }\end{array}$ \\
\hline $\begin{array}{l}\text { Dissemination } \\
\text { and } \\
\text { Communication }\end{array}$ & 82.790 & $\begin{array}{l}\star \star \\
\star \star\end{array}$ & $\begin{array}{c}\text { Planning is done. Modes of } \\
\text { Communication may be } \\
\text { incomplete. However, existing } \\
\text { modes are effective. }\end{array}$ \\
\hline $\begin{array}{l}\text { Early Warning } \\
\text { System }\end{array}$ & 74.050 & $\begin{array}{l}\star \star \\
\star \star\end{array}$ & $\begin{array}{c}\text { Each element of EWS in school is } \\
\text { of quality. Review the results of } \\
\text { other Elements where } \\
\text { improvements are required if } \\
\text { needed. }\end{array}$ \\
\hline
\end{tabular}

Fig. 9 shows the distribution of the Key Elements and EWS using the star rating. It can be observed that the majority of the schools in Lipa City have met the minimum requirement for all the Elements.

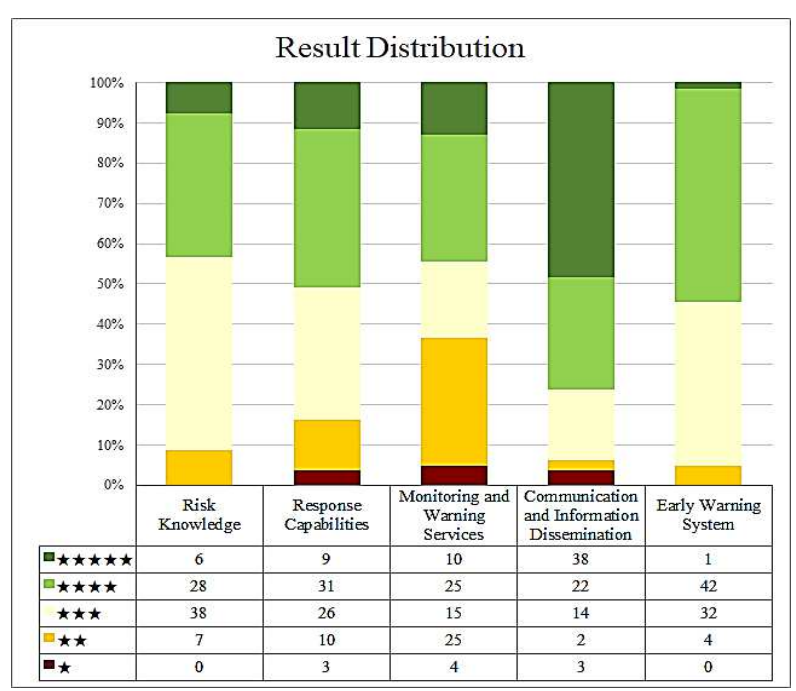

Fig. 9 Distribution of Results

Fig. 10 shows the SOS workshop results conducted in Bulacan using a similar methodology in this paper. It shows a different set of results compared to Lipa City. The results show that Bulacan as a whole has lower scores in all Indexes. This shows that the results for EWS are different and unique for all schools and location. 


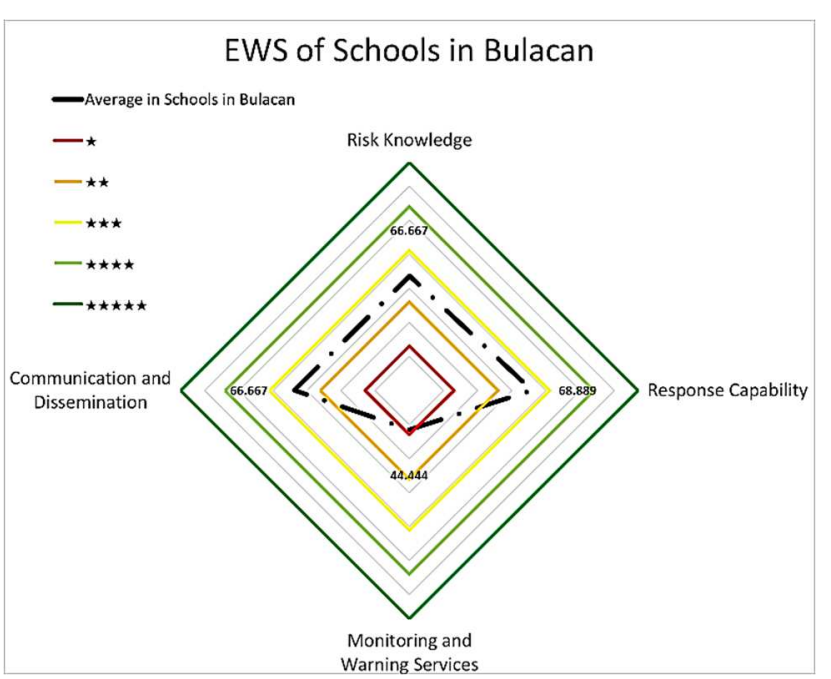

Fig. 10 Average EWS Results of Schools in Bulacan

\section{CONCLUSION}

The proposed MHEWS methodology was able to measure the schools' existing protocols, systems, and devices. The results can show in which aspect a school excels or lacks in the EWS. This can help point out at which aspect the school should improve more to decrease its risk against natural hazards and protect its facility and occupants. This can also help local governments identify which schools in their city or municipality need improvement in their facilities and which utilities and infrastructures to invest in. It is recommended to test different schools and locations to determine a gap between private and public schools or between large and small schools.

\section{A. Risk Knowledge}

Toolkit 1 was used to assess and measure the Risk Knowledge of the school. From the results, it can be concluded that the schools experienced low vulnerability to natural hazards. However, since the school rarely experienced the hazards, the unavailability and lack of usage of hazard maps are high. The earthquake hazard has a higher number of hazard maps in schools than other hazards since it is difficult to forecast compared to other hazards. The majority of the schools have orientations in Disaster Risk Reduction; however, the implementation should be observed in all schools. On average, the schools of Lipa have a Risk Knowledge Index score of 72.257. This falls under the 3-star category, which translates to the majority of schools of Lipa City have met the minimum requirement of the risk knowledge aspect of the EWS in case of hazards.

\section{B. Response Capabilities}

Toolkits 3 and 6 were used to assess and measure the Response Capability of the schools. The Response Capability Index of Lipa City is 72.459. This will fall under the 4-star rating. The score was categorized under the four-star rating. Evacuation in most of the schools was established, and the occupants are aware of what to do when a hazard affects the area. There is also apparent cooperation with the LGU.

\section{Monitoring and Warning Devices}

Toolkit 4 was used to measure the Monitoring and Warning Services of the schools. The results show that the most used mode of warning does not necessarily mean it is also the most effective. The Monitoring and Warning Services Index of the Schools in Lipa City is 68.693. Of all the Indexes, this is the lowest average index of the schools in Lipa City. This distribution of the results is the widest compared to the other key elements. About 29 out of 79 schools have insufficient Monitoring and Warning Services, about 36.71\%, in Lipa City. With this information, investments in improving this key element is highly recommended.

\section{Dissemination and Communication}

Toolkit 5 was used to measure the Dissemination and Communication of the schools. The modes of warning and communication were ranked in terms of the frequency of usage, functionality, and efficiency. For the Modes of Warning, the alarm system ranks the highest, while for the Modes of Communication, considering the three factors, the SMS/Text Blast ranks the highest. The Dissemination and Communication Index of the Schools in Lipa City, Batangas, is 82.790 , giving them a 4-star rating under this category. This means that the Dissemination and Communication of schools for disasters surpass the minimum requirement and is of quality, though there is still room for improvement. Among all the indexes of the EWS, this is the highest score. This shows that the school focuses on information dissemination and communication the most out of all the other elements.

\section{E. Early Warning System}

Based on the toolkits, the participants' answers were recorded and were given a weight depending on the level of vulnerability and risk the schools are exposed to. The weights of the answers are 3, 2, and 1, where 3 is low risk, 2 is medium risk, and 1 is high risk. The Early Warning System of the Schools was evaluated using the toolkits. The importance of each element is equal; hence, to obtain the EWS Index as a whole, the average was obtained, and whatever score would come out would be consistent with the results of each element.

The Early Warning System Index of the schools in Lipa City, Batangas is 74.050 , giving them a 4 -star rating for the EWS. This scoring system can show in which area the schools should focus more on their EWS. Though 74 schools on average have at least a 3-star rating in their EWS, only 45 out of 79 participating schools have met at least the minimum requirement in their EWS. This is because thirty-nine of the participating schools failed in at least one of the elements.

\section{ACKNOWLEDGMENT}

We are grateful to the participants and the local government of Lipa City and Bulacan.

\section{REFERENCES}

[1] J. R. Cadag, M. Petal, E. Luna, J. C. Gaillard, L. Pambid \& G. Santos, "Hidden disasters: Recurrent flooding impacts on educational continuity in the Philippines." International Journal of Disaster Risk Reduction. Aug. 2017. DOI: 10.1016/j.ijdrr.2017.07.016.

[2] Ahsanuzzaman \& M. Q.Islam, "Children's vulnerability International Journal on Advanced Science, Engineering and Information Technology to natural disasters: Evidence from natural experiments in Bangladesh," World Development Perspectives, vol. 19, Jun. 2020. DOI: $10.1016 /$ j.wdp.2020.100228. 
[3] L. Peek, D. Abramson, R. Cox, A. Fothergill, and J. Tobin, "Children and disasters," Handbook of Disaster Research, Nov. 2018, pp. 243262, DOI:10.1007/978-3-319-63254-4 13.

[4] L. Gibbs, J. Nursey, J. Cook, G. Ireton, N. Alkemade, M. Roberts, H. C. Gallagher, R. Bryant, K. Block, R. Molyneaux, and D. Forbes, "Delayed disaster impacts on academic performance of primary school children," Child Development, vol. 90, no. 4, pp. 1402-1412, Jan. 2019, DOI: 10.1111/cdev.13200.

[5] R. B. Jalad. SitRep 15 Magnitude 6.1 Earthquake in Castillejos Zambales (2019). National Disaster Risk Reduction and Management Council, Quezon City, Philippines. 2019.

[6] R. B. Jalad. (Ed.) SitRep No 19 Effects of Magnitude 6.7 Earthquake in Surigao City, Surigao Del Norte (GLIDE No. EQ-2017-000016PHL (2017). National Disaster Risk Reduction and Management Council, Quezon City, Philippines. 2017

[7] E. D. Del Rosario, (Ed.) SitRep No 35 re Effects of Magnitude Sagbayan, Bohol Earthquake (2013). National Disaster Risk Reduction and Management Council, Quezon City, Philippines. 2013.

[8] Geronimo, J. Y. (2013, November 15). Yolanda damaged $90 \%$ of school infra in Tacloban - Luistro. Rappler.

[9] R. B. Jalad, (Ed.) SitRep No 33 re Preparedness Measures and Effects for Tropical Storm "BASYANG” (I.N.) (2018). National Disaster Risk Reduction and Management Council, Quezon City, Philippines. 2018.

[10] S. Torani, P. M. Majd, S. S. Maroufi, M. Dowlati, and R. A. Sheikhi, "The importance of education on disasters and emergencies: A review article," Journal of Education and Health Promotion, vol. 8, no. 85, Apr. 2019, DOI: 10.4103/jehp.jehp 26218.

[11] United Nations General Assembly. (2016). Report of the open-ended intergovernmental expert working group on indicators and terminology relating to disaster risk reduction. Retrieved from https://www.preventionweb.net/files/50683_oiewgreportenglish.pdf.

[12] S. Sufri, F. Dwirahmadi, D. Phung, and S. Rutherford, "A systematic review of Community Engagement (CE) in Disaster Early Warning Systems (EWSs), " Progress in Disaster Science, vol. 5, 100058, 2020. DOI: $10.1016 /$ j.pdisas.2019.100058

[13] S. Sufri, F. Dwirahmadi, D. Phung, and S. Rutherford, "Enhancing community engagement in disaster early warning system in Aceh, Indonesia: Opportunities and challenges," Natural Hazards, vol 103, DOI: $10.1007 / \mathrm{s} 11069-020-04098-2$.

[14] V. Marchezini, R. Trajber, R. Olivato, et al., "Participatory early warning systems: Youth, citizen science, and intergenerational dialogues on disaster risk reduction in Brazil," International Journal of Disaster Risk Science, vol. 8, pp. 390-401, Dec 2017, DOI: 10.1007/s13753-017-0150-9.

[15] D. Satria, S. Yana, E. Yusibani, S. Syahreza, and Zulfan, "Implementation of the SMS gateway in the flood early warning information system for village warning and community information," International Journal of Engineering and Advanced Technology (IJEAT), vol. 8, no. 6, pp. 4005-4009, Aug. 2019, DOI: 10.35940/ijeat.F9287.088619.

[16] K. Goniewicz and F. Burkle. "Disaster early warning systems: The potential role and limitations of emerging text and data messaging mitigation capacities," Disaster Medicine and Public Health Preparedness, vol. 13, no. 4, pp. 709-712, Mar. 2019, DOI: 10.1017/dmp.2018.171.

[17] O. Velazquez, G. Pescaroli, G. Cremen, and C. Galasso, “A review of the technical and socio-organisational components of earthquake early warning systems," Frontiers in Earth Science, vol. 8, p. 445, 2020. DOI: $10.3389 /$ feart.2020.533498.

[18] G. Pescaroli, M. Nones, L. Galbusera, and D. Alexander. "Understanding and mitigating cascading crises in the global interconnected system," International Journal of Disaster Risk Reduction, vol 30, part B, pp. 159-163, 2018. DOI: 10.1016/j.ijdrr.2018.07.004.
[19] I. Aguirre-Ayerbe, M. Merino, S. L. Aye, R. Dissanayake, F. Shadiya, and C. M. Lopez, "An evaluation of availability and adequacy of multi-hazard early warning systems in Asian countries: A baseline study," International Journal of Disaster Risk Reduction, vol. 49, pp. 1-11, Jul. 2020, DOI: 10.1016/j.ijdrr.2020.101749.

[20] United Nations Office for Disaster Risk Reduction. (2017, March). Comprehensive School Safety. [Online]. Available in: https://www.preventionweb.net/files/51335_cssbooklet2017updated. pdf.

[21] R. Paci-Green, A. Varchetta, K. McFarlane, P. Iyer, and M. Goyeneche, "Comprehensive school safety policy: A global baseline survey," International Journal of Disaster Risk Reduction, vol 44, 2020. DOI: 10.1016/j.ijdrr.2019.101399.

[22] M. Petal, K. Ronan, G. Ovington, and M. Tofa, "Child-centered risk reduction and school safety: An evidence-based practice framework and roadmap," International Journal of Disaster Risk Reduction, vol. 49, 2020. DOI: 10.1016/j.ijdrr.2020.101633.

[23] D. D'Ayala, C Galasso, A. Nassirpour, R. K. Adhikari, L. Yamin, R. Fernandez, D. Lo, L. Garciano, and A. Oreta. "Resilient communities through safer schools," International Journal of Disaster Risk Reduction, vol. 45, 2020, DOI: 10.1016/j.ijdrr.2019.101446.

[24] Almufti, I., \& Willford, M.. REDi' ${ }^{\text {TM }}$ Rating System Resilience-based Earthquake Design Initiative for the Next Generation of Buildings [1.0]. 2013. Available in https://www.arup.com , redi_finalversion october-2013-arup-website

[25] N. Sahebjamnia, S. Ali Torabi, and S. Afshin Mansouri, "Building organisational resilience in the face of multiple disruptions," International Journal of Production Economics, vol. 197, Dec. 2017, pp. 63-83, DOI: 10.1016/j.ijpe.2017.12.009.

[26] J. Hillman and E. Guenther, "Organisational Resilience: A Valuable Construct for Management Research?," International Journal of Management Reviews, vol. 23, no. 1, pp. 7-44, 2021, DOI: 10.1111/ijmr.12239.

[27] World Meteorological Organization. "Multi-hazard Early Warning System: A Checklist". March 2018. [Online]. Available: https://bit.ly/2INNhfp

[28] H. P. Rahayu, L. K. Comfort, R. Haigh, D. Amaratunga, \& D Khoirunnisa, "A study of people-centered early warning system in the face of near-field tsunami risk for Indonesian coastal cities". International Journal of Disaster Resilience in the Built Environment, vol. 11, issue 2, pp. 241-262, Jan. 2020. DOI: 10.1108/ijdrbe-10-20190068 .

[29] R. Haigh, D. Amaratunga \& K. Hemachandra, "A capacity analysis framework for multi-hazard early warning in coastal communities," Procedia Engineering, vol. 212, pp. 1139-1146, 2018. DOI: 10.1016/j.proeng.2018.01.147.

[30] National Building Code of the Philippines. Manila, Philippines Available in: https://www.dpwh.gov.ph/DPWH/files/nbc/PD.pdf.

[31] School Disaster Risk Reduction and Management Manual: Booklet 1. Department of Education, Philippines 2012. Available in: http://depedbohol.org/v2/wp-content/uploads/2012/06/DRRMManual Booklet-1 Final-1.pdf

[32] School Disaster Risk Reduction and Management Manual: Booklet 2. Disaster Risk Reduction and Management, Department of Education, Philippines, 2012. Available in: http://depedlacarlota.com/file/drrm/DRRM\%20Manual_Booklet $\% 20$ 2 Final.pdf.

[33] E. Canjels, "The Unit-Weighted Mean - Because Size Matters" SEC, Division of Economic and Risk Analysis Working Paper Series, United States of America March 30, 2020. [Online] Available: https://ssrn.com/abstract=3565305 http://dx.doi.org/10.2139/ssrn.3565305

[34] Philippine Institute for Volcanology and Seismology. Available in: http://faultfinder.phivolcs.dost.gov.ph/. 